\title{
PENANAMAN NILAI-NILAI AGAMA ISLAM PADA ANAK USIA DINI DI TK TAAM ADINDA KEPATIHAN MENGANTI GRESIK
}

\author{
Muhammad Syaikhon \\ Universitas Nahdlatul Ulama Surabaya \\ e-mail:muhammadsay87@unusa.ac.id
}

\begin{abstract}
Abstrak: Penelitian ini adalah jenis penelitian lapangan dengan pendekatan deskriptif kualitatif dengan judul Penanaman Nilai-nilai Agama Islam pada Anak Usia Dini di TK TAAM Adinda Menganti Gresik yang bertujuan untuk 1) mengetahui apa saja nilai-nilai agama Islam yang ditanamkan pada anak usia dini di TK TAAM Adinda Kepatihan Menganti Gresik, 2) mengetahui bagaimana metode penanaman nilai-nilai agama Islam pada anak usia dini di TK TAAM Adinda Kepatihan Menganti Gresik, 3) mengetahui apa saja faktor pendukung serta penghambat penanaman nilai-nilai agama Islam pada anak usia dini di TK TAAM Adinda Kepatihan Menganti Gresik. Penelitian ini berusaha melihat secara mendalam dan memaparkan pelaksanaan penanaman nilai-nilai agama Islam kepada anak usia dini di TK TAAM Adinda Menganti Gresik. Teknik pengumpulan data dilakukan dengan cara observasi, wawancara mendalam, dan dokumentasi. Analisis data dilakukan dengan tiga tahap, yaitu reduksi data, penyajian data, dan penarikan kesimpulan/verifikasi. Hasil penelitian ini adalah: 1) Nilai-nilai agama Islam yang ditanamkan di TK TAAM Adinda Menganti Gresik adalah nilai aqidah, syari'ah (ibadah), dan akhlak. Ketiga nilai tersebut tercover dalam beberapa materi, yaitu aqidah, fiqh, akhlak, asmaul husna, do'a harian, hadis pilihan, sejarah Islam, membaca al-Qur'an dan bahasa Arab. 2) Metode yang diterapkan adalah metode bermain, metode cerita, metode keteladanan, metode pembiasaan, metode demonstrasi, dan metode tanya jawab. 3) Faktor pendukung dalam penanaman nilai-nilai Islam ini di antaranya adalah pendidik memiliki kemampuan dalam menyampaikan ajaran agama Islam, peserta didik dapat meniru gerakan dalam beribadah walaupun belum teratur, dan memiliki buku-buku Islami sebagai penunjang. Sedangkan faktor penghambatnya adalah peserta didik mudah tidak fokus, terbatasnya jumlah pendidik yang menyebabkan kelas kurang kondusif, kurangnya persediaan sarana dan prasarana yang menunjang proses pembelajaran, terbatasnya media pembelajaran sehingga metode yang digunakan dalam pembelajaran pun kurang bervariasi, dan perbedaan latar belakang keluarga dalam pemahaman agama.
\end{abstract}

Kata kunci: nilai, Islam, anak, TK, TAAM,

Abstract: This research is the kind of field research with the approach descriptive qualitative with a title planting Islamic religious values in early childhood in kindergarten taam adinda Menganti Gresik aimed at (1) knows all Islamic religious values that is implanted in early childhood in kindergarten Taam Adinda Kepatihan Menganti Gresik, (2) knowing how a method of planting Islamic religious values in early childhood in kindergarten taam adinda Kepatihan Menganti Gresik, (3) knows all by factors in support of and an impediment to planting islamic religious values in early childhood in Kindergarten Taam Adinda Kepatihan Menganti Gresik. This research trying to see an in-depth and describes the implementation planting Islamic religious values to early childhood in kindergarten Taam Adinda Menganti Gresik. The technique of the data collection was done by means of observation, in-depth interviews, and documentation. Data analysis completed in three stages, namely the reduction of the data, presentation of data, and the withdrawal of conclusion / verification. The result of this research is: (1) Islamic religious values that is implanted in kindergarten Taam Adinda Menganti Gresik is aqidah, syari'ah (ibadah), and akblak. The values are included in some of its material, namely aqidah, figh, akblak, asmaul husna, daily praying, curtained hadis, Islamic history, reading al-Qur'an dan Arabic language. (2) The method applied is playing, story, exemplary, habit, demonstration, and question and answer session. (3) Factors in support of in the planting of Islamic values are educator have the ability in conveying Islamic teachings, students can imitate the movements of in his worship although not regular, and having a supporting 
Islamic books. The resistor factors are the student is easy all out of focus, of the limited number of educator who cause less conducive class, a lack of supplies of facilities and infrastructure that supports the teaching process, learning media limited so that methods used in learning any less varied, and differences in family background in understanding religion.

Keywords: values, Childhood, Kindergarten, TAAM, Adinda

\section{PENDAHULUAN}

Pendidikan adalah usaha untuk menciptakan suasana belajar dan proses pembelajaran kepada peserta didik dalam mengembangkan potensi dirinya. Pendidikan merupakan tanggung jawab bersama antara keluarga, masyarakat, dan lembaga pendidikan. Oleh karena itu, agar tujuan pendidikan dapat tercapai dengan baik maka harus ada kesinergian antara ketiga lingkungan tersebut.

Pentingnya pendidikan di tengah-tengah masyarakat di Indonesia perlu disesuaikan dengan tujuan pendidikan nasional. Tujuan Pendidikan Nasional sebagaimana tercantum pada UU No. 20 Tahun 2003 pasal 3 yaitu pendidikan nasional berfungsi mengembangkan kemampuan dan membentuk watak serta peradaban bangsa yang bermartabat dalam rangka mencerdaskan kehidupan bangsa, bertujuan untuk berkembangnya potensi peserta didik agar menjadi manusia yang beriman dan bertakwa kepada Tuhan Yang Maha Esa, berakhlak mulia, sehat, berilmu, cakap, kreatif, mandiri, dan menjadi warga negara yang demokratis serta bertanggung jawab.

Pendidikan sebagai proses pembelajaran harus bertanggung jawab untuk menjadikan peserta didik tidak hanya sekadar mengenal nilai-nilai kebaikan semata, melainkan menyadarkan kepada mereka untuk mengamalkan nilai-nilai kebaikan tersebut dalam kehidupan sehari-hari sebagai perwujudan karakter atau kepribadian yang mulia. Pada hakikatnya pendidikan bukan hanya sekadar transfer of knowledge akan tetapi sebagai transfer of value, dalam arti penanaman dan pengamalan nilai-nilai akan sangat berarti dalam kehidupan sehari-hari dibandingkan hanya sekadar hafal atau mengetahui nilai-nilai tersebut.

Pendidikan yang ada di Indonesia saat ini masih belum banyak menyentuh ranah afektif bagi peserta didik. Pendidikan yang dilakukan masih terpaku pada perubahan kurikulum, baik kurikulum lokal maupun nasional. Pendidikan agama dan moral yang dilakukan masih belum mendapatkan porsi yang semestinya. Sebagian orang memandang bahwa agama dan ilmu pengetahuan sebagai dua hal yang berbeda dan terpisah satu sama lain. Pemisahan ini sering terjadi dalam dunia pendidikan, padahal untuk membentuk generasi yang intelektual dan religius harus ada keterpaduan antara agama dan ilmu pengetahuan dalam proses pembelajaran.

Pendidikan agama adalah salah satu pendidikan yang sangat penting ditanamkan kepada peserta didik sejak usia dini. Karena pendidikan ini merupakan awal dari pengetahuan-pengetahuan dasar yang harus dimiliki oleh para peserta didik. Usia dini merupakan usia yang paling penting, karena pada usia tersebut merupakan awal bagi pertumbuhan dan perkembangan anak yang membawa ke arah kehidupan selanjutnya.

Dengan perhatian dan kesadaran terhadap pendidikan anak sejak usia dini khususnya pendidikan tentang agama akan memberikan dampak yang positif bagi kehidupan mereka. Apabila nilai-nilai agama telah tertanam kuat pada diri seorang anak maka mereka akan tumbuh dan berkembang dengan memiliki kemampuan untuk mencegah dan menangkal serta membentengi diri mereka dari berbagai pengaruh yang negatif. 
Begitu pula sebaliknya, apabila nilai-nilai keagamaan itu tidak ditanamkan secara maksimal maka yang akan muncul adalah perilaku-perilaku yang kurang baik dan bahkan cenderung menyimpang dari ketentuan-ketentuan agama. Dengan demikian penanaman nilai-nilai keagamaan yang dilakukan sejak dini sangat penting dilakukan untuk membekali anak agar lebih matang menghadapi permasalahan kehidupan.

Oleh karena itu, tidaklah heran jika saat ini semakin disadari betapa pentingnya pendidikan bagi anak usia dini dikarenakan perkembangan kepribadian, sikap, mental, dan intelektual sangat ditentukan dan banyak dibentuk pada usia dini. Hal ini terbukti dengan banyaknya lembaga-lembaga PAUD yang didirikan bahkan sampai ke pelosok desa.

TK Taman Asuh Anak Muslim (TAAM) Adinda merupakan salah satu lembaga pendidikan anak usia dini yang berada di desa Kepatihan kecamatan Menganti kabupaten Gresik. Penanaman nilai-nilai agama Islam di lembaga ini menjadi prioritas utama dalam pembelajaran. Materi agama yang diajarkan tidak hanya sekadar berbentuk teori semata, akan tetapi juga diajarkan secara praktis.

TK Taman Asuh Anak Muslim (TAAM) Adinda adalah salah satu sekolah pendidikan untuk anak usia dini di mana di dalamnya terdiri dari beberapa pengajar yang tidak hanya bertugas memberikan pengajaran kepada anak-anak, namun juga memberikan asuhan atau penjagaan kepada anak-anak tersebut mewakili peran orang tua. TK TAAM Adinda mengajarkan kepada peserta didiknya muatan membaca Al-Quran dimulai dari membaca secara tartil sampai dengan penggunaan metode tertentu untuk mengaji dengan seni. Selain itu, peserta didik juga diajarkan tentang doa-doa harian, hadis-hadis pendek, sholat, ziarah, dan lain-lain.
Berdasarkan latar belakang masalah yang telah diuraikan di atas, maka masalah penelitian ini dapat dirumuskan sebagai berikut. (1) Apa saja nilai-nilai agama Islam yang ditanamkan pada anak usia dini di TK TAAM Adinda Kepatihan Menganti Gresik? (2) Bagaimana metode penanaman nilai-nilai agama Islam pada anak usia dini di TK TAAM Adinda Kepatihan Menganti Gresik? dan (3) Apa saja faktor pendukung serta penghambat penanaman nilai-nilai agama Islam pada anak usia dini di TK TAAM Adinda Kepatihan Menganti Gresik?

Berdasarkan rumusan penelitian di atas maka tujuan yang ingin dicapai dalam penelitian ini adalah sebagai berikut. (1) Untuk mengetahui apa saja nilai-nilai agama Islam yang ditanamkan pada anak usia dini di TK TAAM Adinda Kepatihan Menganti Gresik. (2) Untuk mengetahui bagaimana metode penanaman nilai-nilai agama Islam pada anak usia dini di TK TAAM Adinda Kepatihan Menganti Gresik. (3) Untuk mengetahui apa saja faktor pendukung dan penghambat penanaman nilai-nilai agama Islam pada anak usia dini di TK TAAM Adinda Kepatihan Menganti Gresik.

\section{METODE}

Penelitian ini adalah jenis penelitian lapangan dengan pendekatan deskriptif kualitatif. Penelitian ini berusaha melihat secara mendalam dan memaparkan pelaksanaan penanaman nilai-nilai agama Islam kepada anak usia dini di TK TAAM Adinda Menganti Gresik. Sumber data yang diperoleh adalah melalui orang yang diamati atau orang yang diwawancarai yang meliputi pengurus yayasan, guru, peserta didik, orang tua, dan pihak yang terkait dalam penelitian di TK TAAM Adinda Menganti Gresik. Teknik pengumpulan data dilakukan dengan cara observasi, wawancara mendalam, dan dokumentasi. Analisis data dilakukan dengan tiga tahap, yaitu 
reduksi data, penyajian data, dan penarikan kesimpulan/verifikasi.

\section{HASIL DAN PEMBAHASAN}

\section{Nilai-nilai Agama Islam yang Ditanamkan pada Anak Usia Dini di TK TAAM Adinda}

Undang-Undang Nomor 20 Tahun 2003 tentang Sistem Pendidikan Nasional disebutkan bahwa pendidikan nasional berfungsi mengembangkan kemampuan dan membentuk watak serta peradaban bangsa yang bermartabat dalam rangka mencerdaskan kehidupan bangsa bertujuan untuk berkembangnya potensi peserta didik agar menjadi manusia beriman dan bertaqwa kepada Tuhan Yang Maha Esa, berakhlak mulia, sehat, berilmu, cakap, kreatif, mandiri, dan menjadi warga negara yang demokratis serta bertanggung jawab.

Menurut Musleh Herry di antara nilainilai agama Islam yang sangat mendasar adalah iman, Islam, ihsan, taqwa, dan ikhlas. Sedangkan menurut Tholkhah Hasan, pendidikan agama Islam itu mencakup nilai-nilai keyakinan (aqidah), peribadatan (ritual), dan moral agama (akhlak). ${ }^{1}$

Adapun nilai-nilai yang ditanamkan pada pendidikan anak usia dini di TK TAAM Adinda adalah nilai aqidah, syari'ah (ibadah) dan akhlak. Semua itu tercover dalam beberapa materi, yaitu aqidah, fiqh, akhlak, asmaul husna, do'a harian, hadis pilihan, sejarah islam, membaca al-Qur'an dan bahasa Arab. Hal ini berarti bahwa TK TAAM Adinda telah mengajarkan semua dimensi ajaran agama Islam yang sesuai dengan pendapatnya Thokhah Hasan.

\section{Metode Penanaman Nilai-nilai Agama Islam pada Anak Usia Dini di TK TAAM Adinda}

Adapun metode penanaman nilai agama Islam yang diterapkan di TK TAAM Adinda adalah sebagai berikut.

\section{a. Metode bermain}

Bermain merupakan cara yang paling baik untuk mengembangkan kemampuan anak didik. Sebelum bersekolah, bermain merupakan cara alamiah anak untuk menemukan lingkungan orang lain dan dirinya sendiri. Pada prinsipnya, bermain mengandung rasa senang dan lebih mementingkan proses daripada hasil akhir. ${ }^{2}$

Bermain adalah bagian hidup yang terpenting dalam kehidupan anak. Kesenangan dan kecintaan anak dalam bermain ini dapat digunakan sebagai kesempatan untuk mempelajari halhal yang konkret sehingga daya cipta, imajinasi, dan kreativitas anak dapat berkembang. ${ }^{3}$

Menurut Hetherington dan Parke (1979) yang dikutip oleh Moeslichatoen, mengungkapkan bahwa bermain dapat mempercepat perkembangan kognitif anak. Dengan bermain, akan memungkinkan anak meneliti lingkungan, mempelajari segala sesuatu, dan memecahkan masalah yang dihadapinya. ${ }^{4}$

Berdasarkan hasil wawancara dapat ditemukan bahwa metode bermain yang digunakan oleh TK TAAM Adinda adalah kegiatan permainan yang digolongkan dari beberapa sentra. Sentra-sentra yang digunakan di TK TAAM Adinda adalah sentra persiapan, sentra agama, sentra musik, sentra bahan alam, sentra bermain peran dan sentra balok.

\footnotetext{
${ }^{1}$ Tholkhah Hasan, Pendidikan Anak Usia Dini .... hal. 92.

${ }^{2}$ Mansur, Pendidikan Anak Usia Dini..., hal. 133-134.

${ }^{3}$ Ratna Megawangi, et.al, Pendidikan Yang Patut dan Menyenangkan..., hal. 7.

${ }^{4}$ Moeslichatoen, Metode Pengajaran ..., hal. 71.
} 
Dengan demikian TK TAAM Adinda sangat memperhatikan dunia anak, yaitu belajar sambil bermain agar peserta didik merasa senang dan nyaman dalam belajar. Selain itu, TK TAAM Adinda telah mengadopsi metode bermain dari Beyond Centre and Circle Time (BCCT) dimana dengan cara ini dunia anak dapat dibawa melalui beberapa sentra.

\section{b. Cerita}

Keberhasilan belajar anak sangat dipengaruhi oleh kreativitas guru membuat variasi dan keragaman dalam metode belajar. Cerita merupakan salah satu metode pembelajaran yang menyenangkan selain karena mengandung aspek hiburan (entertain), cerita juga menjadi metode pembelajaran yang tidak menggurui dan fleksibel, di mana anak-anak dapat menjumpai suasana menggembirakan sebagaimana suasana bermain. ${ }^{5}$

Cerita dapat mengubah etika anak-anak, karena sebuah cerita mampu menarik anakanak untuk menyukai dan memperhatikannya. Mereka akan merekam semua doktrin, imajinasi, dan peristiwa yang ada dalam cerita. Apabila dengan dasar pemikiran seperti itu, maka cerita merupakan bagian terpenting yang disukai anakanak bahkan orang dewasa. ${ }^{6}$

Metode cerita yang dilakukan pendidik di TK TAAM Adinda adalah dengan cara bercerita menggunakan ilustrasi gambar cerita berseri dari beberapa buku. Penyampaian cerita dari buku Islami oleh pendidik dengan memperlihatkan gambar, mempermudah anak/peserta didik memahami kehidupan Islam dalam lingkungan keluarga maupun masyarakat. Cerita yang disam- paikan antara lain cerita tentang Nabi dan Rasul, sedekah, dan lain-lain.

Metode cerita dengan menggunakan media gambar cerita berseri dari beberapa buku yang dilakukan oleh TK TAAM Adinda ini sangat tepat sekali, karena dengan begitu pembelajaran menjadi lebih mudah dan menyenangkan serta dapat membuat peserta didik lebih ingat terhadap materi yang telah disampaikan.

\section{c. Keteladanan}

Metode keteladanan adalah metode pembelajaran dengan cara memperlihatkan keteladanan, baik yang berlangsung melalui penciptaan kondisi pergaulan yang akrab antara personal sekolah, perilaku pendidik dan tenaga pendidik lain yang mencerminkan akhlak terpuji maupun tidak secara langsung melalui sejumlah ilustrasi kisahkisah keteladanan. ${ }^{7}$

Belajar dengan cara meniru (learning by imitating) dapat memengaruhi aspek rangsangan dan aspek reaksi dengan cara mengamati halhal yang membangkitkan emosi tertentu pada orang lain, anak-anak bereaksi dengan emosi dan metode ekspresi yang sama dengan orang yang diamati. ${ }^{8}$

Dalam mencontohkan keteladanan di TK TAAM Adinda ada kalimat-kalimat yang perlu dihindari seperti jangan dan tidak boleh berkelahi menjadi sesama teman harus saling menyayangi. Serta secara garis besar hal negatif apapun bentuknya, tidak boleh diperlihatkan di depan peserta didik. Melalui keteladanan ini, para pendidik di TK TAAM Adinda lebih berhatihati dan selektif dalam bersikap di hadapan

\footnotetext{
${ }^{5}$ Tadkirotun Musfiroh, et.al., Cerita dan Perkembangan Anak...,hal. 83.

${ }^{6}$ Abdul Aziz Abdul Majid, al-Qishash fi at-Tarbiyah, ..., hal. 11.

${ }^{7}$ Ramayulis, Ilmu Pendidikan Islam, ( Jakarta: Kalam Mulia, 2002), hal. 154.

${ }^{8}$ Kartini Kartono, Mengenal Dunia Kanak-Kanak, (Jakarta: Rajawali, 1985), hal. 83.
} 
murid-muridnya agar apa yang dilakukan oleh para pendidik dapat ditiru dan dipraktikkan oleh murid-muridnya.

Dengan demikian, para pendidik di TK TAAM Adinda lebih memberikan keteladanan secara praktis di samping dengan keteladanan-keteladanan yang disampaikan dalam bentuk cerita.

\section{d. Pembiasaan}

Metode pembiasaan adalah sebuah cara yang dapat dilakukan untuk membiasakan berpikir, bersikap dan bertindak sesuai dengan tuntutan ajaran agama Islam. ${ }^{9}$

Dengan metode ini para pendidik di TK TAAM Adinda mencoba untuk menjadikan halhal positif menjadi suatu kebiasaan kepada murid-muridnya. Mereka dibiasakan untuk berperilaku sesuai dengan yang diajarkan oleh agama, seperti: makan dan minum dengan menggunakan tangan kanan, sholat dhuha berjamaa'ah sebelum pembelajaran, mengucapkan salam dan bersalaman kepada orang tua dan gurunya, membaca doa sebelum dan sesudah melakukan kegiatan, memakai busana muslim, berkata jujur, saling menyayangi, dan saling menghormati.

Penanaman nilai-nilai agama Islam dengan metode pembiasaan yang dilakukan oleh TK TAAM Adinda dapat membuat peserta didik dapat menerapkan nilai-nilai Islam dalam kehidupan sehari-hari dengan mudah dan tanpa paksaan.

\section{e. Demonstrasi}

Metode mengajar dengan cara memperagakan barang, kejadian, aturan dan urutan melakukan sesuatu kegiatan, baik secara langsung maupun melalui penggunaan media pengajaran

\footnotetext{
${ }^{9}$ Armai Arif, Pengantar Ilmu .... 122.

${ }^{10}$ Muhibbin Syah, Psikologi Pendidikan ..., hal. 203.

${ }^{11}$ Moh. Syafiruddin, Metode Tanya Jawab, Diakses dari http://www.syafir.com/2011/01/08/metode-tanya-jawab.
}

yang relevan dengan pokok bahasan atau materi yang sedang disajikan. ${ }^{10}$

Para pendidik TK TAAM Adinda menggunakan metode ini untuk memberikan ilustrasi dalam menjelaskan informasi kepada anak, karena bagi anak melihat bagaimana suatu peristiwa berlangsung lebih menarik dan merangsang perhatian serta lebih menantang daripada hanya mendengarkan penjelasan guru. Demonstrasi ini digunakan dalam pembelajaran tentang gerakan sholat, berbakti kepada orang tua, dan lain-lain.

Dengan metode demonstrasi ini, TK TAAM Adinda dapat memperagakan gerakan sholat secara langsung yang dapat diamati oleh para peserta didik sehingga mereka dapat dengan mudah memahami dan mempraktikkannya.

\section{f. Tanya Jawab}

Metode Tanya Jawab adalah penyampaian pelajaran dengan jalan pendidik mengajukan pertanyaan dan murid menjawab, atau bisa juga suatu metode di dalam pendidikan di mana pendidik bertanya sedang murid menjawab bahan atau materi yang ingin di perolehnya. ${ }^{11}$

Metode tanya jawab ini sering kali digunakan di TK TAAM Adinda pada waktu kegiatan penutup yang sering disebut dengan istilah recalling, yaitu mengulas kembali materi yang telah diajarkan sebelumnya. Dengan metode ini, para pendidik di TK TAAM Adinda lebih mudah untuk mengetahui kemampuan peserta didiknya.

3. Faktor Pendukung dan Penghambat dalam Kegiatan Penanaman Nilai-Nilai Agama Islam Pada Anak Usia Dini di TK TAAM Adinda

Dalam menanamkan nilai-nilai Islam di TK TAAM Adinda ini bukanlah suatu hal yang mudah. Hal ini tidak terlepas dengan adanya 
faktor pendukung dan penghambat dalam proses pelaksanaannya. Pendidik dituntut untuk dapat membantu, mengarahkan dan membimbing anak dalam pembelajarannya yang sesuai dengan norma kehidupan Islam, karena objek yang mereka didik adalah manusia unik yang memiliki kemampuan dasar untuk dibina cenderung susah diatur.

Berdasarkan hasil pengamatan dan wawancara yang dilakukan oleh peneliti yang menjadi faktor pendukung kegiatan PAUD di antaranya adalah pendidik memiliki kemampuan dalam menyampaikan ajaran agama Islam, peserta didik dapat meniru gerakan dalam beribadah walaupun belum teratur, dan memiliki buku-buku Islami sebagai penunjang.

Sedangkan faktor-faktor yang menghambat proses pengelolaan kegiatan penanaman nilainilai agama Islam, yaitu peserta didik mudah tidak fokus, terbatasnya jumlah pendidik yang menyebabkan kelas kurang kondusif, kurangnya persediaan sarana dan prasarana yang menunjang proses pembelajaran, terbatasnya media pembelajaran sehingga metode yang digunakan dalam pembelajaran pun kurang bervariasi, dan perbedaan latar belakang keluarga dalam pemahaman agama.

Untuk mengatasi kendala-kendala yang dihadapi dalam menanamkan nilai Islam, maka para pendidik TK TAAM Adinda mengambil strategi yang dapat mengubah belajar anak menjadi optimal, antara lain pendidik berusaha untuk menyuguhkan materi pendidikan agama yang bervariasi dan relevan dengan kehidupan anak serta menimbulkan minat dalam diri anak, pendidik selalu menunjukkan sikap kasih sayang dan penuh kesabaran dalam membimbing anak, pendidik berusaha membimbing anak dengan membiasakan berperilaku Islami baik di kelas maupun di luar kelas, pendidik memberikan perhatian khusus bagi anak yang pasif di kelas, serta pendidik memberikan aturan-aturan yang jelas dan konsisten tentang perilaku di kelas.

\section{SIMPULAN DAN SARAN}

Berdasarkan hasil penelitian dan pembahasan yang telah penulis lakukan tentang Penanaman Nilai-nilai Agama Islam pada Anak Usia Dini di TK TAAM Adinda Menganti Gresik, dapat diambil kesimpulan sebagai berikut.

1. Nilai-nilai agama Islam yang ditanamkan di TK TAAM Adinda Kepatihan Menganti Gresik adalah mencakup nilai aqidah, syari'ah (ibadah), dan akhlak. Ketiga nilai itu tercover dalam beberapa materi, yaitu aqidah, fiqh, akhlak, asmaul husna, do'a harian, hadis pilihan, sejarah Islam, membaca al-Qur'an dan bahasa Arab.

2. Penanaman nilai-nilai agama Islam di sekolah dilakukan dengan berbagai metode. Metode penanaman nilai-nilai agama Islam pada anak usia dini yang digunakan di TK TAAM Adinda Kepatihan Menganti Gresik meliputi metode bermain, cerita, keteladanan, pembiasaan, demonstrasi, dan tanya jawab.

3. Dalam menanamkan nilai-nilai Islam di TK TAAM Adinda Kepatihan Menganti Gresik bukanlah suatu hal yang mudah. Hal ini tidak terlepas dengan adanya faktor pendukung dan penghambat dalam proses pelaksanaannya. Faktor pendukung dalam penanaman nilai-nilai Islam ini di antaranya adalah pendidik memiliki kemampuan dalam menyampaikan ajaran agama Islam, peserta didik dapat meniru gerakan dalam beribadah walaupun belum teratur, dan memiliki buku-buku Islami sebagai penunjang. Sedangkan faktor penghambatnya adalah peserta didik mudah tidak fokus, terbatasnya jumlah pendidik yang menyebabkan kelas kurang kondusif, kurangnya persediaan sarana dan prasarana yang 
menunjang proses pembelajaran, terbatasnya media pembelajaran sehingga metode yang digunakan dalam pembelajaran pun kurang bervariasi, dan perbedaan latar belakang keluarga dalam pemahaman agama.

\section{Saran}

Setelah mengadakan penelitian di TK TAAM Adinda Kepatihan Menganti Gresik, maka ada beberapa saran mengenai kegiatan penanaman nilai-nilai agama Islam pada anak usia dini, antara lain sebagai berikut.

1. Bagi Kepala Sekolah TK TAAM Adinda Kepatihan Menganti Gresik

a. Perlu adanya peningkatan serta perawatan sarana dan prasarana sebagai penunjang kegiatan penanaman nilai-nilai agama Islam pada anak usia dini.

b. Perlu adanya pengembangan kompetensi bagi pendidik dan tenaga kependidikan sebagai peningkatan mutu pendidikan.

2. Bagi Pendidik TK TAAM Adinda Kepatihan Menganti Gresik

a. Perlu adanya pengembangan dan peningkatan kreativitas dan inovasi pendidik sebagai upaya penanaman nilai-nilai agama Islam pada anak usia dini.

b. Perlu adanya interaksi yang sesuai dan sinergis dalam menyampaikan penanaman nilai-nilai agama Islam.

3. Orang Tua/Wali

a. Selalu mendukung upaya sekolah dalam membimbing dan mengarahkan peserta didik terutama tentang penanaman nilainilai agama Islam.

b. Perlu adanya sinergitas antara orang tua dan sekolah dalam penanaman nilai-nilai agama Islam baik di sekolah maupun di rumah.

\section{DAFTAR PUSTAKA}

Amir al-, Najib Khalid. 2002. Min Asalibi arRasul fi at-Tarbiyah, terj. M. Iqbal Haetami, Mendidik Cara Nabi Saw. Bandung: Pustaka Hidayah.

Arif Armai. 2002. Pengantar Ilmu dan Metodologi Pendidikan Islam, Jakarta: Ciputat Press. Arsyad Azhar. 2003. Media Pembelajaran, Jakarta: Rajawali Pers.

Aziz Abdul dan Abdul Majid. 2003. al-Qishash fi at-Tarbiyah, terj. Syarif Hade Masyah dan Mahfud L. Hakif, Mendidik Anak Lewat Cerita. Jakarta: Mustaqim.

Depag RI. 1989. Al-Qur'an dan Terjemahnya, hal. 336. Semarang: CV Toha Putra.

Dimas Muhammad Rasyid. 2005. Siyasat Tarbawiyah Khathiah, terj. Sari Narulita, 20 Kesalahan dalam Mendidik Anak, Jakarta: Rabbani Press.

Dimyati dan Mudjiono. 2006. Belajar dan Pembelajaran. Jakarta: Rineka Cipta.

Darajat Zakiah. 1996. Pendidikan Islam dalam Keluarga dan Sekolah. Jakarta: Bulan Bintang.

—. 1998. Kesehatan Mental, Cet. 9. Jakarta: Gunung Agung.

Hasan Tholkhah. 2009. Pendidikan Anak Usia Dini dalam Keluarga. Jakarta: Mitra Abadi Press.

J.W. Creswell. 2010. Research Design: Pendekatan Kualitatif, Kuantitatif, dan Mixed Methodes, Yogyakarta: PT Pustaka Pelajar.

Kartono Kartini. 1985. Mengenal Dunia KanakKanak. Jakarta: Rajawali.

Mansur. 2005. Pendidikan Anak Usia Dini dalam Islam. Yogyakarta: Pustaka Pelajar.

Megawangi Ratna, et al. 2004. Pendidikan Yang Patut dan Menyenangkan. Jakarta: Rineka Cipta. 
Moeslichatoen. 2004. Metode Pengajaran di Taman Kanak-Kanak. Jakarta: Rineka Cipta. Moleong Lexy. J. 2013. Metodologi Penelitian Kualitatif, bandung:PT Remaja Rosdakarya.

Morrison George S. Tanpa Tahun. Early Childhood Education Today, Fourth Edition. London: Merill Publishing Company.

Mudjab Mahalli A. 2001. Menikablah, Engkau Menjadi Kaya. Yogyakarta: Mitra Pustaka.

Mukminan. 2004. Desain Pembelajaran. Yogyakarta: Program Pascasarjana Universitas Negeri Yogyakarta.

Mursi Muhammad Said. 2001. Melahirkan Ilmu Pendidikan Anak Masya Allah. Jakarta: Cendekia.

Musfiroh Tadkirotun, et al. 2005 Cerita dan Perkembangan Anak. Yogyakarta: Navila.

Pusat Pembinaan dan Pengembangan Bahasa. 1998. Kamus Besar Bahasa Indonesia. Jakarta: Balai Pustaka.

Ramayulis. 2002. Ilmu Pendidikan Islam. Jakarta: Kalam Mulia.

Salma Dewi \& Eveline Siregar. 2004. Mozaik Teknologi Pendidikan. Jakarta: Prenada Media bekerjasama dengan Universitas Negeri Jakarta.

Sudrajat Ajat, dkk. 2008. Din Al-Islam. Yogyakarta: UNY Press.

Sudono Anggani. 2000. Sumber Belajar dan Alat Permainan: Untuk Pendidikan Anak Usia Dini. Jakarta: Grasindo.

Suparno Paul, dkk. 2002. Reformasi Pendidikan Sebuah Rekomendasi. Yogyakarta: Kanisius.

Sururin. 2004. Ilmu Jiwa Agama. Jakarta: Raja Grafindo Persada.

Syah Muhibbin. 2000. Psikologi Pendidikan dengan Pendekatan Baru. Bandung: Rosda Karya.
Syantut Asy-, Khalid Ahmad. 2005. Rumah: Pilar Utama Pendidikan Anak. Jakarta: Rabbani Press.

Shihab Quraish. 1998. Membumikan Al Qur'an. Bandung: Mizan.

Tarazi Norma. 2003. The Child in Islam: a Muslim Parent's Handbook, terj. Nawang Sri Wahyunngsih, Wahai Ibu Kenali Anakmu: Pegangan Orang tua Muslim Mendidik Anak. Bandung: Mitra Pustaka.

Tafsir Ahmad. 1994. Ilmu Pendidikan dalam Perspektif Islam. Bandung: Remaja Rosda Karya.

Tanzeh Ahmad. 2009. Metode Penelitian Praktis. Yogyakarta: Teras.

Thoha Chabib. 1996. Pendidikan Islam. Yogyakarta: Pustaka Pelajar.

Wahyudi, CHA., Dwi Retna Damayanti. 2005. Program Pendidikan Untuk Anak Usia Dini di Prasekolah Islam. Jakarta: Gramedia Widya Sarana Indonesia.

Wiryasumarta Y. 2003. Pentingnya Pendidikan di TK dalam Perilaku Anak Usia Dini Kasus dan Pemecahannya. Yogyakarta: Anggota IKAPI.

Moh. Syafiruddin. 2014. Metode Tanya Jawab, Diakses dari http://www.syafir.com/2011/ 01/08/metode-tanya-jawab pada tanggal 7 September 2014, jam 17.22 WIB.

Musleh Herry. 2006. Kenalkan Agama Sejak Dini. Diakses dari http://pesantren.or.id. 29.masterwebnet.com/dalwa.bangil/cgibin. pada tanggal 15 September 2014, jam 19.15 WIB.

Wikipedia. 2007. Early Chilhood Education. Diakses dari http://en.wikipedia.org/wiki/ early_chilhood_education. Pada tanggal 2 September 2014, jam 11.11 WIB. 
Education and Human Development Journal, Vol. 3, No. 1, April 2018 